\title{
THE THUNDERBOLT AS A SIGN OF GOD IN OROSIUS' SEVEN BOOKS OF HISTORY AGAINST THE PAGANS
}

\section{Introduction}

Events connected to the sacking of Rome by the Visigoths, under the leadership of Alaric in 4IO, echoed widely throughout the Roman world and became fixed in many literary works of the time. Among these, the "Seven Books of History against the Pagans" by the Spanish priest, Paulus Orosius, commands an important place. This work originated in the years 4I6-4I7, most probably in Carthage. While it is of great significance in the research of the history of ideas, it is less so as a source of historical events. These last, while numerous, are basically taken from the works of earlier historians ${ }^{2}$, which is also evident from the assumptions of the author, and the request of St. Augustine, who was to be the spiritus movens of the work ${ }^{3}$. In response to the behest of St. Augustine, and the otherwise unknown to us monk, Julian, from Carthage, Orosius collects information preserved in earlier works, about disasters that had befallen mankind throughout history. From the outset, writing to St. Augustine in the preface to Book I of the "History", he details which events he intends to present:

"I have obeyed your instructions, most blessed father Augustine [...]. You instructed me therefore to set out in a book, concisely and in order, all the troubles caused by wars, the ravages of disease, the sorrows caused by hunger, the terrible events brought about by earthquakes, the unexpected disasters caused by floods, the terror caused by volcanic eruptions, the savagery of lightning strikes and hailstorms, and the misery

\footnotetext{
On Orosius, see: F. Fabrini, Paolo Orosio uno storico, Roma 1979; S. Koczwara, Orozjusz, EK 14, Lublin 2010, 825; F. Paschoud, Orosio, NDPAC 2, Genova 2007, 3688-3691. For this article, we have benefitted from the following publication and translation: Orosius, Historiarum aduersus paganos libri VII: Orose, Histoires (Contre les Païens), tome 1. Livres I-III, tome 2. Livres IV-VI, tome 3. Livre VII, texte établi et traduit par Marie-Pierre Arnaud-Lindet, Les Belles Lettres, Paris 1990-1991. Orosius, Seven Books of History against the Pagans, translated with an introduction and notes by A.T. Fear, Liverpool University Press, Liverpool 2010, "Translated Texts for Historians" 54.

2 Cf. F. Paschoud, Orosio, NDPAC 2, 3691.

3 Scholars have a variety of opinions as to the credibility of the information presented by Orosius. Cf. I. G. Mastrorosa, Calamità e prodigi nella storia di Roma repubblicana: la rilettura tardoantica di Orosio, "Les épitomés scientifiques et historiques" 8, 2012, p. 2, [http://rursus.revues.org/1084 ; DOI: 10.4000/rursus.1084], Accessed 15 Dec. 2016.
} 
caused by parricide and other such crimes, found in times gone by that I could discover in all the records of the histories and annals which are to be had at the present time".

This article is devoted to the analysis of one occurrence from the list - the thunderbolt, taking account of the frequency of its occurrence, the times, the circumstances, the effects and significance. Basically, in tracing the ideas of the author, we shall keep to his chronological order whilst indicating any deviations which would be justified by the content.

\section{Before the founding of Rome}

Orosius discusses the times before the founding of Rome in the first book of his work. He cites two events in which thunderbolts occur, and in both cases, he explains the significance of the occurrence. The first concerns the destruction of the area of Pentapolis:

" 1,160 years before the foundation of the City, Cornelius Tacitus, among others, relates that the region neighbouring Arabia which was then called the Pentapolis was set ablaze down to its soil by fire from heaven, speaking as follows: Not far away are those plains which men say were once fertile and supported great domains, but which were burnt up by a thunderbolt and they say that traces of this disaster still remain and that the very earth has been made solid and lost its power to be fertile. Although here he says nothing about the cities being consumed by fire because of the sins of their inhabitants, as if he were ignorant of this matter, a little later he forgets himself and reveals the facts by adding: I grant that these famous cities were indeed once set ablaze by fire from heaven, but believe that it is the fumes from the lake that infected and corrupted the land. In saying these things, albeit most unwillingly, about cities that were without a doubt consumed because of the vileness of their sins, he admits that he knows this and holds it to be the truth, and so openly shows that he does not lack belief in what he has found out, but rather the willingness to expound that belief"5.

This event is also known in biblical history as the destruction of Sodom and Gomorrah ${ }^{6}$. However, for the sake of the pagan reader, for whom his work is intended, Orosius rarely draws on this source. In this case of the thunderbolt he relies on Tacitus' "Histories".

\footnotetext{
4 "Praeceptis tuis parui, beatissime pater Augustine [...]. Praeceperas ergo ut, ex omnibus qui haberi ad praesens possunt historiarum atque annalium fastis, quaecumque aut bellis grauia aut corrupta morbis aut fame tristia aut terrarum motibus terribilia aut inundationibus aquarum insolita aut eruptionibus ignium metuenda aut ictibus fulminum plagis que grandinum saeua uel etiam parricidiis flagitiis que misera per transacta retro saecula repperissem, ordinato breuiter uoluminis textu explicarem"; Orosius, Historiae I. Prologus 1, 10, ed. M.-P. Arnaud-Lindet, vol. 1, p. 6, 8, tr. A.T. Fear, pp. 31-32.

5 "Ante annos Vrbis conditae MCLX confinem Arabiae regionem quae tunc Pentapolis uocabatur arsisse penitus igne caelesti inter alios etiam Cornelius Tacitus refert, qui sic ait: «Haud procul inde campi quos ferunt olim uberes magnis que uiribus habitatos fulminum iactu arsisse; sed manere uestigia, terram que ipsam, specie solidam, uim frugiferam perdidisse». Et cum hoc loco nihil de incensis propter peccata hominum ciuitatibus quasi ignarus expresserit, paulo post uelut oblitus consilii subicit et dicit: «Ego sicut inditas quondam urbes igne caelesti flagrasse concesserim, ita halitu lacus infici terram et corrumpi reor». Quo dicto inuitus licet de exustis urbibus, quae procul dubio peccatorum noxa conflagrauerunt, et scisse se et concessisse confessus palam prodidit non sibi cognitionis fidem defuisse sed exprimendae fidei uoluntatem"; Ibidem I, 5,1-5, ed. M.-P. Arnaud-Lindet, vol. 1, pp. 45-46, tr. A.T. Fear, p. 52.

6 Description cf. Gen 19, the names of the towns listed by Orosius cf. Gen 14,1-2.
} 
Twice, in this extract, the Spanish historian uses the term "fire from heaven" (ignis caelestis ${ }^{7}$ ), and once, writes about thunderbolts (fulminum iactus ${ }^{8}$ ), treating them as synonyms. He also highlights that although in the first quoted extract Tacitus does not mention the cities, yet in the second, as though forgetting this, he writes about the burnt cities, ascribing their fall also to mephitis emitted from the lake9. Orosius himself also interprets the meaning of the described event, writing that the cities were turned to ash as a punishment for sins. Describing the moral disorder within the cities which was also the cause of the destruction of the whole region, he concludes:

"And so God in His wrath rained down fire and sulphur on this land and burnt up the entire region along with its peoples and cities, damning them to eternal perdition that thenceforth they might be a witness to His judgement"10

Orosius collates the destruction of Sodom to the sacking of Rome by the Goths in 4IO, regarding both cases as God's punishment of the cities. What occurred in the region of Pentapolis teaches us that God punished and will punish sinners ${ }^{\mathrm{II}}$, whereas that which occurred in Rome was only a warning of the disasters which might be forthcoming.

The thunderbolt which killed Aremulus, king of the Latins, also bore the character of a punishment. The historian does not develop this line of thought, dedicating only a short paragraph to Aremulus. However, as with the earlier description, he interprets the meaning of this sign, stating that the untimely death of the king was as a result of God's judgement and a long overdue punishment ${ }^{12}$. As Orosius reports, he perishes by a thunderbolt by God's judgement (fulmine interceptus) because "he flourished amidst his crimes and impiety for eighteen years".

To sum up this part of the analysis, we can state that the two thunderbolts of which Orosius writes in Book One of the "History" have the character of punishment for a wicked life, as the author clearly states. Reference to the sacking of Rome by the Goths, an event contemporary with the author, points to another meaning of this sign, that of a warning from God ${ }^{13}$.

\section{The History of Rome to Augustus}

In the second preface within the work, introducing the Fourth Book of the "History", Orosius states that present events, whatever they are, always appear more grievous than those

\footnotetext{
Orosius, Historiae VII,5,1; VII,5,4.

8 Ibidem VII,5,2.

9 Preserved manuscripts, the first extract also give information about the cities: „Haud procul inde campi, quos ferunt olim uberes magnis que urbibus habitatos fulminum iactu arsisse; et manere vestigia terram que ipsam specie torridam vim frugiferam perdidisse" (Cornelius Tacitus, Historiae 5,7)

10 „Itaque iratus Deus pluit super hanc terram ignem et sulphur totam que regionem cum populis atque urbibus exustam, testem iudicii sui futuram, aeterna perditione damnauit"; Orosius, Historiae I, 5,9, ed. M.-P. Arnaud-Lindet, vol. 1, pp. 45-46, tr. A.T. Fear, p. 53.

11 Cf. Ibidem I, 6,1-6.

12 "Diuino iudicio fulmine interceptus matura supplicia inmatura aetate dissoluit"; Ibidem I,20,5, ed. M.-P. Arnaud-Lindet, vol. 1, p. 72, tr. A.T. Fear, p. 69.

13 This question will be further discussed in the last section of the article.
} 
of the past and those of the future ${ }^{14}$. He introduces his intention to present the disasters and difficulties which the Romans must have experienced throughout their history ${ }^{15}$.

The historian begins his presentation by describing the background to, and the course of the war against Pyrrhus. As he says, the first battle of this war which the Romans waged against Pyrrhus at Heraclea proved to be a huge defeat for Rome, magnified by the even worse natural disasters which occurred after it. A storm arose, catching unaware their providers of supplies, causing destruction with terrible thunderbolts (fulminibus exussit), resulting in great losses of people and pack animals ${ }^{16}$. Orosius is at pains to explain the meaning of this event. He had indicated this earlier when he had announced how he would present the disasters of bygone times. The key to his interpretation is in the description of the event itself where he underlines the enormity of the destruction, stating "it was rightly said that this was not the sign of destruction to come, but an act of destruction in its own right"17. He returns to this topic again on completing the description of the Pyrrhic war, pointing out that the misfortunes of the Romans and God's anger did not abate, and describing the diseases which occurred then as an expression of God's anger ${ }^{18}$.

Somewhat later Orosius writes of a series of ruinous and awful scrying signs (obscena et dira prodigia), which occurred in Rome 478 years after its founding (269 BC):

" 470 years after the foundation of the City, vile, terrible portents were seen, or news given of them, at Rome. The Temple of Health was destroyed by a lightning bolt and part of the city wall in the same place was also struck as they say, 'from the heavens'. [...] At Formiae, the entire city wall was burnt up and destroyed by lightning bolts"19.

In this relatively short excerpt there are three signs concerning thunderbolts: The Temple of Salus was destroyed by a thunderbolt (ictu fulminis), part of the city wall in the same place was struck from heaven (de caelo tacta est), which should probably also be interpreted as a thunderbolt. In the town of Formiae, the city walls were burnt and destroyed on all sides by many thunderbolts (multis ictibus fulminum). Orosius does not attribute any meaning to the listed prodigia. However, it would seem that the hypothesis formulated by I. G. Mastrorosa merits agreement. It places the extract in the context of the events above, showing the ambiguity of Roman military ethics, where even the sentencing to death of a whole Roman legion is regarded as a victory ${ }^{20}$. In the

14 Cf. Ibidem IV. Prologus 3.

15 Cf. Ibidem IV. Prologus 11.

16 "Interea Romanus exercitus, postquam uictus clam fugit e castris, miserabilem belli cladem grauioribus monstris auctam accumulatam que persensit. Nam pabulatores forte progressos uelut hostilis quaedam oborta tempestas cum horribili fragore caeli correptos diris fulminibus exussit. Quippe XXX et IIII eorum idem turbo prostrauit; duo et uiginti semineces relicti; iumenta exanimata et capta conplurima: ut merito contigisse non in signum uastationis futurae sed uastatio ipsa referatur"; Orosius, Historiae IV,1,16-18, ed. M.-P. Arnaud-Lindet, vol. 2, p. 13.

17 Ibidem IV,1,16-18, tr. A. T. Fear, p. 158.

18 Cf. Ibidem IV,2,1.

19 „Anno ab Vrbe condita CCCCLXX obscena et dira prodigia uel uisa Romae uel nuntiata sunt. Aedes Salutis ictu fulminis dissoluta, pars muri sub eodem loco de caelo, ut dicunt, tacta est. [...] Apud Formias multis ictibus fulminum moenia undique ambusta et dissoluta sunt"; Ibidem IV,4,1.3, ed. M.-P. Arnaud-Lindet, vol. 2, p. 16, tr. A.T. Fear, p. 160. The text contains the description of one more prodigium: Fire which burst forth from a crevice in the land of Cales (cf. ibidem VI,3,4).

20 When, probably in the year $271 \mathrm{BC}$, the eighth legion plundered Rhegium and murdered the inhabitants, they were flogged and put to death in the Forum. Orosius comments on this information: ,Visa sibi est tunc Roma uin- 
whole text, prodigia complete a grim picture of the period discussed, as proven by the further events presented in the "History"2.

Further signs already appear in Orosius' transcript of events in the last century of the republic, and are contained in the Fifth Book of "History". One sign, described as obscene and tragic (obscenum prodigium ac triste), was the death of the daughter of Lucius Helvius. This Roman knight was surprised by a storm when returning to Rome from Apulia with his wife and daughter. Seeing that his daughter was terrified, and wishing to hasten their return home, he left his coaches, placing his maiden daughter, on horseback, in the middle of the travellers. The girl was instantly struck dead by a thunderbolt (ictu fulminis) ${ }^{22}$. Her body was intact, but her clothes were stripped from her together with all her necklaces and rings. Immediately after this, Orosius cites an instance where three Vestals had broken their vows of chastity, and were punished by death ${ }^{23}$. It was this instance, a sign of the corruption and fall of the mainstay of the Roman Republic which were the Vestals, which was supposedly foretold by the death of the daughter of Lucius Helvius. As I. G. Mastrorosa has already observed, perhaps Orosius was linking this to the previous extract ${ }^{24}$. Immediately before these accounts, Orosius describes the fate of the king of Numidia, Jugurtha. After being captured, he was led in triumph before Marius, and soon after was strangled in prison. During his earlier stay in Rome, writes Orosius, Jugurtha "either bribed or tempted everybody", and on leaving the city, reportedly said "Oh City for sale and doomed do die - if only you can find a buyer!" 25 This is another possible understanding of the sign given by the death of the knight's daughter - in both cases, however, Orosius indicates the fall of the institution of the Roman Republic.

Orosius also attributes the death of Pompeius Strabo to a thunderbolt (Pompeius fulminate afflatus interiit $)^{26}$. This is one of the traditional views already formed in antiquity on the death of Pompeius, In Orosius' narrative, the death of the commander is set within a very long description of civil wars, their horror grimly underlined by Orosius. Orosius therefore emphasises Rome's defeat and the fall of the Republic. However, one might ask if this is not also a punishment which condemns the evils brought about by civil wars. If we consider the aversion or downright hatred towards Pompeius ${ }^{27}$, interpreting his death by thunderbolt as punishment, appears justified ${ }^{28}$.

cere, cum legionem suam integram occidit, quae sine dubio uicta fuisset, si eam hostili proelio perdidisset"; Ibidem IV,3,6, ed. M.-P. Arnaud-Lindet, vol. 2, p. 16.

21 Cf. I.G. Mastrorosa, Calamità e prodigi, p. 15.

22 Cf. Orosius, Historiae V,15,20n.

23 Cf. Ibidem V,15,22. See Iulius Obsequens, Liber prodigiorum 37.

24 Cf. I. G. Mastrorosa, Calamità e prodigi, p. 23.

25 "O urbem uenalem et mature perituram, si emptorem inuenerit!” Cf. Orosius, Historiae V,15,5, ed. M.-P. Arnaud-Lindet, vol. 2, p. 113, tr. A.T. Fear, p. 231.

26 Orosius' short description about the death of Pompeius, and the events around it states: "Pompeius fulmine adflatus interiit; exercitus uero eius pestilentia correptus paene totus absumptus est. Nam undecim milia uirorum de castris Pompei mortua, sex milia autem de parte Octauii consulis desiderata sunt"; Ibidem V,19,18, ed. M.-P. Arnaud-Lindet, vol. 2, p. 135, tr. A.T. Fear, p. 247.

27 This aspect - which is already contained within ancient sources such as Plutarch, Granius Licinianus, Julius Obsequens, has been examined by T. W. Hillard, in an article devoted to the death of the commander. Cf. T. W. Hillard, Death by lightning. Pompeius Strabo and the People, "Rheinisches Museum Für Philologie", 139(1996), no. 2, p. 138.

28 Together with the above convention about the death of Pompeius by thunderbolt, antiquity also formed another, whereby the commander died as a result of the plague. Both are validated by sources, but even extensive research 
As a whole, the events cited in this section of the work have certain new features unknown earlier. Above all, there is the emphasis on the onerousness of past events, as well as the condemnation of evil in Rome's history, of civil wars which destroy the state, and the breach of religious principles.

\section{The age of Empire}

During the period of Empire, discussed by Orosius in the Seventh Book of "History", Orosius notes new circumstances in which thunderbolts appear - the persecution of Christians. He observes, that after the persecutions, events occurred which were regarded as disasters even by the enemies of the Church, and which Orosius interprets as punishments:

"The Church of Christ suffered ten persecutions from Nero to Maximian. Nine times vengeance, as I have put it, or disaster, as they would not deny, followed in their wake. I will not argue about words and debate whether the things both of us call disasters were due punishment or unfortunate changes of circumstance" 29 .

Orosius notes the first thunderbolt in the context of Trajan's persecutions ${ }^{30}$. There were a series of cataclysms in his day, punishments for the persecutions: Nero's Golden House, he being the first persecutor of Christians, was burnt down, there were earthquakes in Asia, Greece, Galatia, there was a bloody rebellion of the Jews in the East ${ }^{{ }^{3}}$, and also the Pantheon was burnt down as a result of a thunderbolt (Pantheum Romae fulmine concrematum) ${ }^{32}$. The first of the cataclysms, the burning of Nero's Golden House, is obviously presented as a punishment which touches the initiator of the persecutions i.e. $\mathrm{Nero}^{33}$, as well as the perpetrator, i.e. Trajan, by the destruction of the place from which he controlled the Empire ${ }^{34}$.

The next thunderbolt described by Orosius occurred during the so-called "rain miracle" and "thunderbolt miracle", in the reign of Marcus Aurelius, during the Marcomannic wars. Orosius informs us, that during the fighting, the Roman army reached the borders of the Quadi, and found itself in a tragic situation. It was surrounded by enemies, and because of the lack of water, was exhausted and near to annihilation. At that point, after the public prayers

\footnotetext{
has not been able to clearly establish which is correct. Consequently, on current research, it would appear necessary to accede to the opinion of O.D. Watkins, that ,the truth about the death of Strabo may well have died with him”; cf. O. D. Watkins, The Death of Cn. Pompeius. Strabo, "Rheinisches Museum Für Philologie“ 131(1988) 150.

29 "Decem persecutiones a Nerone usque ad Maximianum Ecclesia Christi passa est: nouem, ut ego dixi, ultiones, ut ipsi non negant, calamitates e uestigiis consecutae sunt. Nec in uerbo premo, utrum debitae ultiones an fortuitae permutationes fuisse uideantur, quae tamen meo suo que testimonio clades fuerunt", Orosius, Historiae VII,26,9, ed. M.-P. Arnaud-Lindet, vol. 3, p. 69, tr. A.T. Fear, pp. 364-365.

30 As Orosius explains, Trajan started the persecutions because he was misled. He ordered that Christians be forced to make sacrifices to the gods, and those who refused to be put to death. Many were thus killed. As a result of Pliny's intervention, who examined the matter of the Christians closely, Trajan mitigated his edict; cf. Ibidem VII, 12,3.

31 Cf. Ibidem VII, 12,4-8.

32 Ibidem VII,12,5, ed. M.-P. Arnaud-Lindet, vol. 3, p. 44.

33 In Christian antiquity, Nero was commonly regarded as the first persecutor, although, both the number of persecutors and persecutions has been variously presented by authors; cf. J. Numowicz, Ile było prześladowań Kościoła starożytnego? Opinie autorów patrystycznych, in: Lux ex Silesia. Księga Pamiątkowa dedykowana Księdzo Profesorowi Józefowi Mandziukowi w 70. rocznicę urodzin, ed. W. Gliński, Warszawa, 2013, p. 500.

34 ,Verumtamen continuo Romae aurea domus, a Nerone totis priuatis publicis que rebus inpensis condita, repentino conflagrauit incendio, ut intellegeretur missa etiam ab alio persecutio in ipsius potissime monumentis, a quo primum exorta esset, atque in ipso auctore puniri”, Orosius, Historiae VII,12,4, ed. M.-P. Arnaud-Lindet, vol. 3, p. 44.
} 
of "some soldiers" to Christ, the rain poured. It not only refreshed the Romans, but forced the barbarians to flee. Moreover, thunderbolts rained on the positions of the Quadi, many of whom were killed. (fulminum ictibus). The small and inexperienced group of Romans pursued the enemy and cut them down, thanks to the great aid of Christ ${ }^{35}$.

The event itself, the historical foundations of which appear legitimate and which probably occurred in I72, took shape in two traditions: pagan and Christian. The former, widely verified in literature, numismatics, epigraphy and the arts, was also exploited by Marcus Aurelius' propaganda ${ }^{36}$. However, it is the Christian trend of interpretation which is presented by Orosius, which came on the scene very early, towards the end of the 2nd century ${ }^{37}$. Here he prescribes the miracle to Christ, who saved the Roman army from defeat and death, one instrument of the rescue being the thunderbolts which struck their opponents.

Commodus, son of Marcus Aurelius, succeeded to the Empire. The historian briefly mentions his successful wars, yet he concentrates on the depraved transgressions of the Emperor, his debauchery, and obscenities. He also cites the Emperor's battles in the arena during the games dressed as a gladiator, and his participation in battles with wild beasts. He also states that Commodus killed many senators ${ }^{38}$. Behaviour like this is followed by punishment:

“The City's punishment followed in the wake of the king's wrong-doing. The Capitol was struck by lightning which started a fire-storm that gripped and burned down, along with some buildings adjacent to it, the library which their ancestors had taken great care to build. After this, another fire then broke out at Rome and razed to the ground the temple of Vesta, the Palace, and a good part of the City" ${ }^{39}$.

The thunderbolt which strikes prophetically during the reign of Emperor Aurelian has a different significance. Orosius presents his military exploits in a very positive manner, ending with: "Aurelian therefore held a triumph in glory as the man who had recovered both

\footnotetext{
35 „Hoc quidem bellum prouidentia Dei administratum esse cum plurimis argumentis tunc praecipue epistula grauissimi ac modestissimi imperatoris apertissime declaratum est. Nam cum insurrexissent gentes inmanitate barbarae, multitudine innumerabiles, hoc est Marcomanni, Quadi, Vandali, Sarmatae, Sueui atque omnis paene Germania, et in Quadorum usque fines progressus exercitus circumuentus que ab hostibus, propter aquarum penuriam, praesentius sitis quam hostis periculum sustineret, ad inuocationem nominis Christi, quam subito magna fidei constantia quidam milites effusi in preces palam fecerant, tanta uis pluuiae effusa est ut Romanos quidem largissime ac sine iniuria refecerit, barbaros autem crebris fulminum ictibus perterritos, praesertim cum plurimi eorum occiderentur, in fugam coegerit. Quorum terga Romani usque ad internecionem caedentes gloriosissimam uictoriam et omnibus paene antiquorum titulis praeferendam rudi paruo que militum numero, sed potentissimo Christi auxilio reportarunt"; Ibidem VII,15,7-10, ed. M.-P. Arnaud-Lindet, vol. 2, pp. 48-49.

36 See I. Israelowich, The Rain Miracle of Marcus Aurelius: (Re-) Construction of Consensus, "Greece \& Rome. Second Series" 50(2008), no. 1, pp. 83-102.

37 With reference to this interpretation, see M. Ziółkowski, ,, Cud deszczu” w 172 r. i chrześcijanie, „Acta Universitatis Nicolai Copernici. Historia” vol. 27 (254), 1992, pp. 89-95

38 „Aduersus Germanos bellum feliciter gessit. Ceterum per omnia luxuriae et obscenitatis dedecore deprauatus, gladiatoriis quoque armis saepissime in ludo depugnauit et in amphitheatro feris sese frequenter obiecit; interfecit etiam quamplurimos senatores, maxime quos animaduertit nobilitate industria que excellere"; Orosius, Historiae VII,16,2, ed. M.-P. Arnaud-Lindet, vol. 3, p. 50.

39 „Flagitia regis poena Vrbis insequitur: nam fulmine Capitolium ictum ex quo facta inflammatio bibliothecam illam, maiorum cura studio que compositam, aedes que alias iuxta sitas rapaci turbine concremauit. Deinde aliud incendium postea Romae exortum aedem Vestae et Palatium plurimam que Vrbis partem solo coaequauit"; Ibidem VII,16,3, ed. M.-P. Arnaud-Lindet, vol. 3, p. 50, tr. A.T. Fear, pp. 348-349.
} 
the east and the north. He surrounded the city of Rome with stronger walls" ${ }^{40}$. However, when the Emperor determined to proclaim his persecution of Christians, he was struck by a thunderbolt which filled those around with terror. The Emperor was killed soon after ${ }^{4}$.

Orosius returns to this event again towards the end of his description of the persecutions, comparing the persecution of Christians with the Egyptian plagues. He writes about the meaning of the thunderbolt (triste fulmen) during the Aurelian persecution:

"Here, the ninth reproof was the same - a terrible and terrifying thunderbolt fell in a horrifying whirlwind at Aurelian's feet as he was in the act of proclaiming his persecution. This thunderbolt showed what so powerful an Avenger could do, when there was so great a call for vengeance, were He not both merciful and restrained"42.

In the light of these words, the thunderbolt which strikes during the Aurelian persecution takes on the meaning of punishment, of warning, and a manifestation of God's power.

Emperor Carus dies from a thunderbolt (fulmine ictus interiit). This occurred in 284, however, as we have already seen in some extracts, Orosius presents the event without further comment. The description itself is very short and doesn't allow conclusions other than the death of the Emperor was one of the misfortunes which befell the Empire and the Romans in past times ${ }^{43}$.

\section{The sack of Rome by the Goths}

In Orosius' narrative, the sack of Rome by the Goths, under the command of Alaric in 4IO, which he describes in detail in Book Seven of the "History", has a particular place. This event is presented within the context of the activities of Stilicho who - as the historian informs us - sought to transfer imperial power to his son Eucherius exploiting the barbarian tribes to this end. In turn, Eucherius himself announced that having acceded to power he would rebuild the pagan temples and demolish churches ${ }^{44}$. Consequently God's wrath ${ }^{45}$ and punishment ${ }^{46}$ befell the city in the form of enemy invasion. However, the Goths turned out

\footnotetext{
40 "Sic Orientis et Aquilonis receptor magna gloria triumphauit. Vrbem Romam muris firmioribus cinxit"; Ibidem VII,23,5, ed. M.-P. Arnaud-Lindet, vol. 3, p. 61, tr. A.T. Fear, p. 359.

41 "Nouissime, cum persecutionem aduersus Christianos agi nonus a Nerone decerneret, fulmen ante eum magno pauore circumstantium ruit ac non multo post in itinere occisus est"; cf. Ibidem VII,23,6, ed. M.-P. Arnaud-Lindet, vol. 3, pp.61-62, tr. A.T. Fear, p. 359.

42 "Hic itidem nona correptio fuit cum Aureliano persecutionem decernenti diris turbinibus terribile ac triste fulmen sub ipsius pedibus ruit, ostendens quid, cum ultio talis exigeret, tantus possit ultor, nisi et clemens esset et patiens"; Ibidem VII,27,12, ed. M.-P. Arnaud-Lindet, vol. 3, p. 73, tr. A.T. Fear, p. 367.

43 „Anno ab Vrbe condita MXXXVIIII, Carus Narbonensis tricesimus secundus suscepit imperium ac biennio tenuit. Qui cum filios suos Carinum et Numerianum consortes regni effecisset, bello Parthico postquam duas nobilissimas Parthorum urbes Cochem et Ctesiphontem cepit, super Tigridem in castris fulmine ictus interiit"; Ibidem VII,24,4, ed. M.-P. Arnaud-Lindet, vol. 3, pp. 62-63.

44 Cf. Ibidem VII,38,1-6.

45 „Accidit quoque, quo magis illa Vrbis inruptio indignatione Dei acta quam hostis fortitudine probaretur, ut beatus Innocentius, Romanae ecclesiae episcopus, tamquam iustus Loth subtractus a Sodomis occulta prouidentia Dei apud Rauennam tunc positus, peccatoris populi non uideret excidium"; Ibidem VII,39,2, ed. M.-P. Arnaud-Lindet, vol. 3 , p. 114.

46 „Itaque post haec tanta augmenta blasphemiarum nullam que paenitentiam ultima illa diu que suspensa Vrbem poena consequitur"; Ibidem VII,38,7, ed. M.-P. Arnaud-Lindet, vol. 3, p. 113.
} 
to be exceptionally clement and pious ${ }^{47}$, and after three days left the city of their own free will having set only a few buildings alight ${ }^{4}$. Orosius compares this invasion with earlier defeats and states that they were much more tragic 49 .

After presenting the tragedy and atrocities of earlier events as well as the unusually peaceful course of Alaric's invasion, the author notes:

"And so that no one should doubt that the enemy was allowed to do this in order to punish the arrogant, debauched, blasphemy of the town, at this same time the most famous buildings in the City which the enemy was unable to set alight were destroyed by lightning" 50 .

The destruction of the famous buildings of the City by thunderbolts (fulminibus diruta sunt), is therefore a sign that the conquest of Rome by the Goths was in agreement with the will of God, as well as an instrument of God's punishment of the "arrogant, debauched and blasphemous" inhabitants.

The same theme of juxtaposition of two invasions appears also in Book Two of the "History" 5 . The invasion by the Gauls - in Orosius' presentation - was a huge disaster for the Romans, and the destruction of the city so complete, that leaving it was a consideration ${ }^{52}$. The invasion of the Visigoths in 4IO AD was diametrically opposite to the one just described. Here he also emphasises that the Goths only stayed in the city for three days, controlled their greed for plunder, and not only did they not murder the inhabitants but actually led them to sanctuary in the churches ${ }^{53}$. The actual departure of the Goths from the city, shows, as indicated by the thunderbolt, that the whole event was part of God's plans, and God's then rage, rather than man's. As the Goths were leaving, having shown themselves to be so benign, the Forum with all the statues therein, which were evidence and tools of the cult of paganism, was struck by thunderbolts (ictu fulminum), and lay in ruins. For these statues,

47 Orosius vividly describes how they escorted the Christians to the Basilica, particularly a virgin of Christ together with religious vessels which they had found with her, (cf. Ibidem VII, 39,3-10), which was a sign of their piety and religious respect.

48 Ibidem VII,39,15.

49 The burning of "a few buildings" by the Goths is used in the theme of comparing this event to the great fires which occurred in Rome: the first dated 700 from the founding of Rome i.e. 52 BC. (Orosius writes about this event in Historiae VI, 14,5, dating it 52 BC as well as in VII,2,11. For more about the date and sources see the footnote in A.T. Fear: Orosius, Seven Books of History, p. 291, note 186) and the second event which arose as a result of the burning of Rome for the Emperor Nero in 64 A.D. Again, in the text, we come across a comparison between the sacking of Rome by the Goths, and the invasion by the Gauls eight centuries earlier. The author emphasises that three days after entering Rome, the Goths left of their own free will, while reminding us that during their invasion, the Gauls " held Rome, treading on the ashes of the burnt and destroyed City for almost a year". It is worth noticing how Orosius exaggerates the invasion of the Gauls, if only where he describes their stay in Rome for a year, whereas in II, 19, 13, he informs us that the occupation "raged on for six months".

50 „Et ne quisquam forte dubitaret ad correptionem superbae lasciuae et blasphemae ciuitatis hostibus fuisse permissum, eodem tempore clarissima Vrbis loca fulminibus diruta sunt quae inflammari ab hostibus nequiuerunt"; Orosius, Historiae VII,39,18, ed. M.-P. Arnaud-Lindet, vol. 3, p. 117, tr. A.T. Fear, p. 404.

51 The thunderbolt referred to in the text was to have occurred during the invasion of 410 , which is why it is discussed here.

52 Cf. Ibidem II, 19,5-11.

53 Cf. Ibidem II, 19,12n. This comparison is fairly obvious from the perspective of the main line of thought of the work, which is the comparison of the times in which the author lives with past times. He demonstrates that greater disasters abounded in past times, compared to those experienced by the Romans in the times of Orosius. 
arising from a regretful superstition, gave a false image of God and of man - and it is this which appears as another motif of God's anger and the destructive purpose of the thunderbolts. In this way, that which enemy flames had not reached, was consumed by flames from the heavens (missus a caelo ignis euertit) ${ }^{54}$.

\section{Conclusions}

This analysis of Orosius" "History" against the Pagans allows for a number of conclusions.

In the preface to his work, addressing Augustine of Hippo, Orosius announces that he will present an account of the misfortunes which befell mankind through the ages, including tragedies caused by the savagery of lightning strikes. In the whole of his work, Orosius cites over a dozen episodes in which these phenomena occur, at various times and in various circumstances, having different effects and diverse meanings, in many instances simply determined by Orosius himself. Thunderbolts are always presented by the author as exceptional signs of God's power and might.

Chronologically, Orosius records two thunderbolts which occurred in the times before the foundation of Rome. In both cases, they have the character of a punishment for moral disorder and in both accounts the author himself interprets them as such.

In the history of Rome to Augustus, Orosius noted four instances of unusual thunderbolts. These instances are all within Books Four and Five - in accord with the main idea in the work and the announcement within the preface to the Fourth Book - the shared keynote is, above all, the disasters which the Romans endured throughout their history. Events in the times of the later republic are also described in a grim tone, a sign of which are the prodigia, (among them, also thunderbolts), which occurred then. Orosius also has a negative attitude to civil wars and Rome's military ethics, portraying the corruption of society as well as the fall of the Roman Republic. -

During the Empire, thunderbolts appear in a new context, which is the persecution of Christians. Thunderbolts are one punishment which befalls the Empire during the reign of the Emperor - persecutors. A new theme of this period is also the thunderbolt as an occurrence which saves the Romans in the "miracle of the thunderbolt" during the Marcomannic Wars. Also present, as known from earlier entries, is the theme of the thunderbolt as a punishment for immorality (as in the case of Commodus), as well as in the case of Carus' death by thunderbolt, where it is difficult to interpret it otherwise than one of the disasters which befell the Empire.

Orosius pays much attention to the conquest of Rome under the leadership of Alaric in 4IO. The thunderbolt, which also appears during this event, is significant in several ways. Above all it signifies that the conquest of Rome by its enemies was in accord with the will of God, and, at the same time a punishment of the inhabitants for their conceit, depravity and idolatry. The event itself, which was received with horror in the Empire, generated debate, and, in a certain sense, gave rise to the Histories. However, Orosius presents the invasion

\footnotetext{
54 „Plane quod re proditur et fatendum est: in hac clade praesenti plus Deum saeuisse, homines minus, cum, peragendo ipse quod illi non inpleuissent, cur eos miserit, demonstrauit. Quippe cum supra humanas uires esset incendere aeneas trabes et subruere magnarum moles structurarum, ictu fulminum forum cum imaginibus uanis quae superstitione miserabili uel Deum uel hominem mentiuntur, abiectum est; horum que omnium abominamentorum, quod inmissa per hostem flamma non adiit, missus e caelo ignis euertit”; Ibidem II,19,14-15, ed. M.-P. Arnaud-Lindet, vol. 1, p. 127.
} 
of the Goths as an episode in the thousand years of Rome's history. It was an opportune admonition, a call to conversion, and the thunderbolt was an obvious tool for God to use. The event itself, enters Orosius' vision of history and temporal order, which he cannot imagine otherwise than based on Rome, and strengthened by the unity of faith in the true God 55 .

\section{The Thunderbolt as a Sign of God in Orosius' Seven Books of History against the Pagans Summary}

In the preface to the "Seven Books of History against the Pagans" Orosius announces that he will present different disasters which affected mankind throughout history, and mentions among them thunderbolt strikes. The article aims at analysing the descriptions of this phenomenon from the point of view of their circumstances, time, results and meanings. The study shows that although the circumstances are different, it was always God who sent down the lightning strikes and spoke through them. Orosius dedicates a lot of attention to the sacking of Rome by the Visigoths in 4IO AD, which ended also with a lightning strike. The analysis of this and of other descriptions shows Orosius' vision of history and the temporal order based on the power of Rome and faith in the true God.

Keywords: Orosius, Sevens Books of History against the Pagans, thunderbolt, sign, portent

\section{Piorun jako znak Boga w Historiach przeciw poganom Orozjusza Abstrakt}

Orozjusz we wstępie do „Historii przeciw Poganom” zapowiada przedstawienie nieszczęść, jakie dotknęły ludzkość w ciągu dziejów, a wśród nich wymienia uderzenia piorunów. Celem artykułu jest analiza opisów tego zjawiska zawartych w dziele pod kątem okoliczności, czasów, skutków i znaczenia. Studium pozwala stwierdzić, że choć powyższe warunki są zróżnicowane, to jednak zawsze Bóg zsyłał uderzenia i przez nie przemawiał. Wiele miejsca Orozjusz poświęca zdobyciu Rzymu przez Wizygotów w 4Io r., które zakończyło się także uderzeniem pioruna. Analiza tego i innych opisów ukazuje orozjuszową wizję dziejów i porządku ziemskiego opartego o potęgę Rzymu i wiarę w prawdziwego Boga.

Słowa kluczowe: Orozjusz, Historie przeciw poganom, piorun, znak, znak wróżebny

Nota o Autorze: Ks. dr Tomasz Skibiński SAC, patrolog i historyk specjalizujący się w badaniach późnego antyku i wczesnego średniowiecza w Zachodnim Cesarstwie Rzymskim i królestwach sukcesyjnych na Zachodzie. Zastępca Dyrektora Instytutu Nauk Historycznych w Uniwersytecie Kardynała Stefana Wyszyńskiego w Warszawie.

55 A. Marcone A., Il Sacco di Roma del 410 nelle riflessioni di Agostino e di Orosio, "Rivista storica italiana", 114 (2002), nr 3, p. 864. 